\title{
SZABADSÁGVESZTÉS-BÜNTETÉSÜKET TÖLTŐKK LAKÓHELYEINEK TÉRBENI ELHELYEZKEDÉSE BUDAPESTEN
}

\author{
(Residential segregation of imprisoned offenders in Budapest) \\ LADÁNYI JÁNOS
}

Tanulmányunkban elốször a börtönbüntetésüket töltôk egyes csoportjai lakóhelyeinek térbeni elhelyezkedését vizsgáljuk meg Budapesten. Mindenekelổtt arra vagyunk kíváncsiak, hogy e csoportok lakóhelyei mennyire esnek egybe a legalacsonyabb státusú népesség, illetve a leghátrányosabb helyzetư etnikai kisebbség, a cigányság, lakóhelyeinek koncentrálódási pontjaival, illetve arra, hogy hogyan alakul a börtönbüntetésre ítéltek különbözố csoportjai lakóhelyi szegregációjának intenzitása. A tanulmány végén néhány általánosabb megjegyzést teszünk a hátrányos társadalmi helyzet és a bû́nözés összefüggésével, illetve a bũnmegelôzéssel és bưnüldözéssel kapcsolatos jelenlegi rendôri gyakorlattal kapcsolatban.

\section{A börtönbüntetésüket töltók lakóhelyeinek térbeni eloszlása}

Tudomásunk szerint eddig még senki sem vizsgálta meg Budapesten a bebörtönzöttek különbözổ csoportjai lakóhelyeinek térbeni elhelyezkedését, sớt arról sem tudunk, hogy bármilyen bưnözéssel kapcsolatos adatból kerületinél részletesebb tudományos igényư feldolgozás készült volna az utóbbi évtizedek során. Vizsgálódásunk alapsokaságául az 1979. október 31-én szabadságvesztés-büntetését töltổ felnổttkorúak (18 évnél idôsebbek) közül állandó vagy ideiglenes budapesti lakcímmel rendelkezð̋, de nem munkásszálláson vagy nevelóotthonban lakók (2284 fố) szolgáltak. A meglehetốsen távoli idổpontot részben az magyarázza, hogy ezen adatok korábbi nyilvános publikálása komoly nehézségekbe ütközött volna. Ugyanakkor elmondható az is, hogy mivel jelenleg még mindig csak az 1980 legelején végzett népszámlálás adatai azok, amelyekbốl városrendezési körzetenkénti bontåsban adatok állnak rendelkezésre, és mivel a szegregációs számításoknál igen fontos az egymással összehasonlítható adatok használata, az a körülmény, hogy adataink az 1979-es év végérốl származnak, végül is még szerencsésnek is tekinthetố. Egyébként sem nagyon valószínứ, hogy - néhány, késổb kiemelésre kerülổ körülménytốl eltekintve - a fớbb tendenciák azóta lényegesen megváltoztak volna.

A bebörtönzötteket elôször különbözổ kategóriákba soroltuk, majd lakcímeiket - az egyes kategóriákat más-más számmal jelölve - munkatérképre rajzoltuk. Munkánkhoz egy igen részletes, Budapest minden egyes házát és telkét feltüntetố, 1200 szelvényes térképet használtunk segítségül. A különbözổ színũ pontokat városrendezési körzetenként (1980-ban 490 ilyen körzet volt) összeszámoltuk, és a kapott adatokat, a népszámlálásból nyert kiegészítố adatokkal együtt, számítógépre vittük. E pontozásos módszer legnagyobb elổnye abban rejlik, hogy segítségével nemcsak a vizsgált jelenség népszámlálási körzetenkénti eloszlása, hanem esetleg az ezeket a körzeteket átlapoló, vagy a népszámlálási városrendezési körzeteknél kisebb csomósodási pontok megragadására is lehetôség nyílik. 
Elôször a szóban forgó népesség összetételét azokban a dimenziókban fogjuk megvizsgálni, amelyek mentén lehetôség nyílik a budapesti átlagpopulációval való összehasonlításra. A rendelkezésre álló adatok sajnos nem teszik lehetôvé, hogy a 18 évesnél idôsebb bebörtönzöttek adatait a 18 évesnél idôsebb budapesti népességgel vessük egybe. Ezért az alábbi összehasonlításokban csak a 20 éves és idôsebb népesség adatait elemezzük.

\section{TÁBLÁZAT}

A húsz éves és idổsebb budapesti és az 1979-ben börtönbüntetését töltổ népesség megoszlása életkor szerint, \%

(Distribution of the population in Budapest (over 20 years of age) and of those in prison in 1979 by age group, \%)

\begin{tabular}{lcr}
\hline 1. Életkor & 2. Bebörtönzöttek & 3. Budapest (lakónépesség)* \\
\hline & & \\
$20-24$ & 19,1 & 8,8 \\
$30-29$ & 28,8 & 11,3 \\
$35-39$ & 18,1 & 10,1 \\
$40-44$ & 12,9 & 9,5 \\
$45-49$ & 8,0 & 7,6 \\
$50-54$ & 5,5 & 8,3 \\
$55-59$ & 4,0 & 9,0 \\
$60-$ & 2,0 & 9,1 \\
4. Összesen & 1,6 & 26,3 \\
\hline
\end{tabular}

*Forrás: 1980. évi népszámlálás 1. kötet, Budapest adatai II. 8-9. old.

1. Age

2. Imprisoned

3. Budapest (residents)

4. Total

Az adatok tanúsága szerint a valamilyen okból bebörtönzött húsz évnél idốsebb népesség általában jóval fiatalabb, mint a budapesti átlagpopuláció. Míg a bebörtönzöttek csaknem fele, addig a húsz évesnél idốsebb budapestieknek csak egyötöde fiatalabb 29 évnél. Ezzel szemben mig a bebörtönzötteknek csak 1,6\%-a, a budapestieknek több mint egynegyede idốsebb, mint 60 éves. 
Ladányi János : Szabadságvesztés-büntetésüket töltők lakóhelyeinek térbeni elhelyezkedése Budapesten (Residential segregation of imprisoned offenders in Budapest)

Tér és Társadalom 5. évf. 1991/4. 17-35. p.

\section{TÁBLÁZAT}

A huisz éves és idôsebb budapesti és az 1979-ben börtönbüntetését töltổ népesség megoszlása iskolai végzettség szerint, \%

(Distribution of the population in Budapest (over 20 years of age) and of those in prison in 1979 by their educational level, \%)

1. Iskolai végzettség

4. Befejezetlen általános iskola

5. Befejezett általános iskola

6. Befejezetlen szakmunkásképzó

7. Befejezett szakmunkásképzó

8. Befejezetlen egyéb középfokú iskola

9. Befejezett egyéb középfokú iskola

10. Befejezetlen felsơfokú iskola

11. Befejezett felsôfokú iskola

12. Adathiány

13. Összesen

*Forrás: u.o.

1. Educational level

2. Imprisoned

3. Budapest (residents)

4. Unfinished primary school

5. Finished primary school

6. Unfinished vocational training school

7. Finished vocational training school
2. Bebörtönzöttek

3. Budapest (lakónépesség)*

$\begin{array}{rc}13,4 & 22,9 \\ 46,8 & 28,8 \\ 4,0 & 0,3 \\ 18,1 & 7,9 \\ 2,6 & 1,5 \\ 11,1 & 24,1 \\ 0,3 & 2,0 \\ 2,2 & 12,5 \\ 1,5 & -\end{array}$

100,0

100,0

A fenti megoszlások összevetésébốl nyilvánvaló, hogy a bebörtönzöttek jóval kevésbé iskolázottak a budapesti átlagnépességnél. Ez az eltérés különösen jelentốs, ha azt is figyelembe vesszük, hogy a bebörtönzöttek általában jóval fiatalabbak, és a fiatalabb generációk iskolai végzettsége általában jelentổsen felülmúlja az idổsebbekét.

A bebörtönzöttek $60 \%$-ának legmagasabb iskolai végzettsége csak 8 vagy ennél is kevesebb osztály, és ha egyáltalán jártak valamilyen középiskolába, ez inkább szakmunkásképzố vagy szakiskola volt, és csak minden ötvenedik rendelkezik közülük valamilyen felsôfokú végzettséggel. Ugyanakkor azonban az általában jóval idôsebb fồvárosiaknak csak a fele rendelkezik legfeljebb 8 osztályos iskolai végzettséggel, a középiskolába jártak inkább gimnáziumot végeztek, és közülük minden nyolcadiknak valamilyen felsôfokú diplomája van. Ennél is jelentôsebbek az eltérések, ha a megoszlásokat egy-egy korcsoporton belül vetjük össze, ettốl azonban terjedelmi okok miatt eltekintünk.

Rátérve most már a vizsgált népesség térbeni eloszlásának vizsgálatára, az elemzést elöször a legfelszínesebb összevetést lehetôvé tévô adminisztrativ kerületek szerinti bontásban elvégezve is kitưnik a börtönbe kerülés gyakoriságának a lakóhely státusával való erốs összefüggése. A börtönbüntetésüket töltốk aránya éppen a legalacsonyabb státusú, nagykiterjedésú, 
Ladányi János : Szabadságvesztés-büntetésüket töltök lakóhelyeinek térbeni elhelyezkedése Budapesten (Residential segregation of imprisoned offenders in Budapest)

Tér és Társadalom 5. évf. 1991/4. 17-35. p.

slumosodó területeket magába foglaló belsố pesti kerületekben (VI., VII., VIII., IX. kerületek) haladja leginkább meg, és a legmagasabb státusú, budai, társasházas kerületekben (II., XI., XII. kerületek) marad legjobban alatta az átlagpopuláció ezen kerületekben kimutatható arányának.

\section{TÁBLÁZAT}

Az 1979-ben börtönbüntetésüket töltôk, valamint a budapesti lakónépesség megoszlása lakóhelyük szerint, \%

(Residential distribution of imprisoned offenders in 1979 and of the population as a whole in Budapest, \%)

\begin{tabular}{ccc}
\hline 1. Kerïletek & 2. Bebörtönzöttek & 3. Budapest (lakónépesség) \\
\hline I. & 1,5 & 2,2 \\
II. & 2,8 & 5,3 \\
III. & 4,4 & 5,6 \\
IV. & 3,4 & 3,9 \\
V. & 2,8 & 2,7 \\
VI. & 4,5 & 3,7 \\
VII. & 7,4 & 4,9 \\
VIII. & 7,8 & 5,4 \\
IX. & 6,7 & 4,4 \\
X. & 6,0 & 4,6 \\
XI. & 4,7 & 8,4 \\
XII. & 1,8 & 4,0 \\
XIII. & 8,7 & 6,8 \\
XIV. & 6,4 & 8,1 \\
XV. & 5,5 & 5,4 \\
XVI. & 3,0 & 3,5 \\
XVII. & 2,8 & 2,7 \\
XVIII. & 4,1 & 4,5 \\
XIX. & 3,2 & 3,0 \\
XX. & 6,1 & 5,0 \\
XXI. & 3,5 & 3,5 \\
XXII. & 2,9 & 2,4 \\
\hline 4. Összesen & 100,0 & 100,0 \\
\hline
\end{tabular}

1. Districts

2. Imprisoned

3. Budapest (residents)

4. Total

A továbbiakban éppen arra vagyunk kíváncsiak, hogy hogyan függ össze a vizsgált népesség térbeni elhelyezkedése a különbözổ státusú területek térbeni eloszlásával. Ezért elemzésünket elôször a népszámlálásoknál használatos területi egységek közül a legkisebb, de itt még értelmesen használható területi egységre, a 490 városrendezési körzetre fogjuk elvégezni. A területi elkülönülés erôsségének mérésére egyszerüsége és közismertsége miatt a Duncan házaspár által bevezetett (Duncan és Duncan 1955) szegregációs és disszimilaritási indexeket fogjuk használni. Mint ismeretes, az utóbbi indexet úgy képezik, hogy két népességcsoport területegységek 
Ladányi János : Szabadságvesztés-büntetésüket töltök lakóhelyeinek térbeni elhelyezkedése Budapesten (Residential segregation of imprisoned offenders in Budapest)

Tér és Társadalom 5. évf. 1991/4. 17-35. p.

TÉT $1991=4$

Szabadságvesztés-büntetésüket töltók Budapesten

szerinti százalékos megoszlásai területegységenkénti különbségeinek abszolút értékeit összegzik és osztják kettổvel. A szegregációs index képzése hasonló módon történik, csak ekkor nem két kiemelt népességcsoport egymáshoz viszonyított eloszlását, hanem egy kiemelt népességcsoport eloszlását vetik egybe az egész maradék népesség térbeni eloszlásával. Ezen index maximális értékét, vagyis 100-at, akkor veszi fel, ha a két megoszlás egymást teljesen kizáró, minimális értékét, vagyis 0 -át pedig akkor, ha a két megoszlás teljesen megegyezik egymással. Szokás a szegregációs indexet úgy is értelmezni, mint azoknak az arányát, akiknek más területi egységekbe kellene költözniük ahhoz, hogy a vizsgált népesség eloszlása nem térjen el az átlagpopuláció térbeni eloszlásától.

Adataink szerint a vizssált népesség térbeni elkülönülését kifejezố szegregációs index — városrendezési körzetenként és összehasonlításként a 14 éven felüli, nem intézeti háztartásokban lakó népességgel számolva $-20,4$ volt. Ezen érték megitéléséhez némi támpontul szolgálhat ha megemlítjük, hoy a segéd- és betanított munkások hasonló feltételek mellett mért elkülönülése 17,0, a budapesti cigány népességé pedig 53,9 volt. Ha az eltérô esetszámok (bebörtönzöttek: 2284 fó, cigányok: 3889 fổ, segéd- és betanított munkások: 263 ezer fố) okozta torzításokat is megkíséreljük figyelembe venni megállapíthatjuk, hogy a bebörtönzöttek térbeni elkülönülésének erốssége hasonló mértékú, mint a legalacsonyabb státusú társadalmi-foglal kozási csoport térbeni elkülönülése, ami a bebörtönzöttek igen alacsony átlagos iskolázottsági szintjének ismeretében nem nagyon meglepó. Mindkét csoport térbeni elkülönültségét magasan felülmúlja viszont a cigány kisebbség szegregálódásának mértéke, amit nemcsak e népességcsoport igen alacsony társadalmi-foglalkozási státusa, hanem az etnikai jellegũ szegregáció jellegzetességei (Ladányi 1989) is magyaráznak.

Hasonló eredményre vezet az említett népességcsoportok lakóhelyeinek térbeni elhelyezkedését bemutató térképek (l-3. ábra) egymással való összevetése is. (Sajnos nyomđatechnikai okok miatt csak erósen leegyszerũsített, és ezért az eredetieknél sokkal kevésbé pontos térképek bemutatására van lehetổségünk.) Mint máshol ezt már bốvebben kifejtettük (Ladányi 1988), a különbözô társadalmi státusú népesség térbni elhelyezkedésére Budapesten egyfelố a legmagasabb státusúak lakóhelyeinek a budai társasházas területeken való erổs, nagykiterjdésû koncentrálódása, másfelố a legalacsonyabb státusúaknak a város pesti oldalán, több mikroszegregátumban való tömörülése a jellemzổ. A budapesti cigány népesség térbeni elhelyezkedésének mintája jelentổsen eltér ettôl; mind a cigányok által igen magas arányban lakott területek (régi állami bérlakásokkal beépített, leromló, belsố pesti slumos körzet), mind az olyan területek, ahol szinte egyáltalán nem laknak cigányok (budai társasházas területek) nagykiterjedésú, összefüggỏ részeket alkotnak. A fenti mintákkal szemben a börtönbüntetését töltổ népesség térbeni elhelyezkedése sokkal egyenletesebbnek tekinthetổ, és a bebörtönzöttek különbözổ területeken való elốfordulásának gyakorisága lényegében két jelentổs eltéréssel ezen területek beépítésének intenzitását követi. $\mathrm{E}$ két jelentổs eltérés lényege röviden abban ragadható meg, hogy - mivel az átlagosnál sokkal alacsonyabb státusú népességról van szó - a bebörtönzöttek felülreprezentáltak a belsố pesti slumosodó területeken, és alulreprezentáltak a magasstátusú budai részeken. 


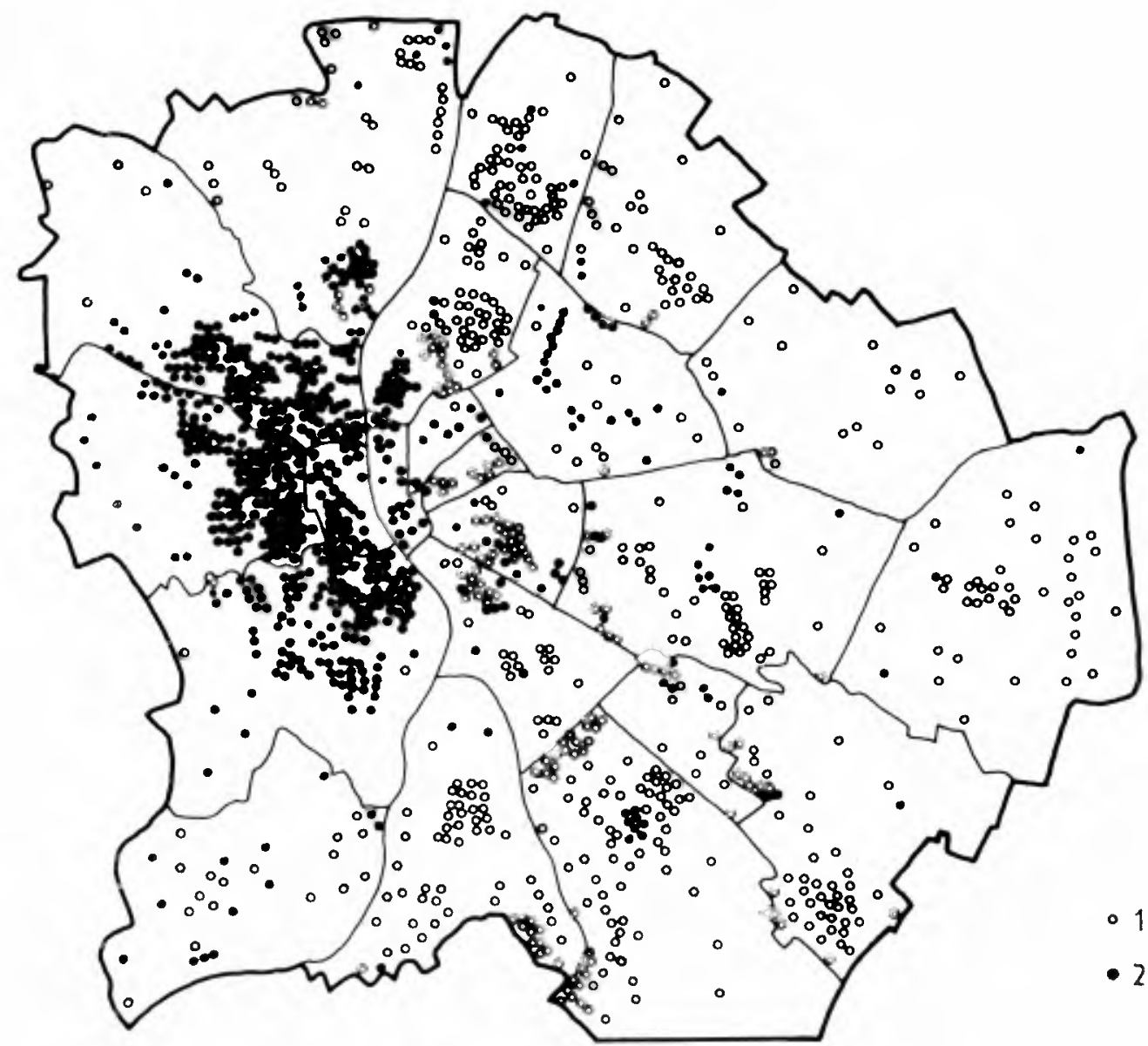

1. ÁBRA

A kvalifikálatlanok aktiv keresókön belüli aránya szerint sorbarendezett számlálókörzetek legfelsón

és legalsó decilisei Budapesten 1980-ban

(Semi-skilled and unskilled economically active workers in Budapest, 1980)

$1=$ Alsó decilis (lower decile)

$2=$ Felsô decilis (upper decile) 


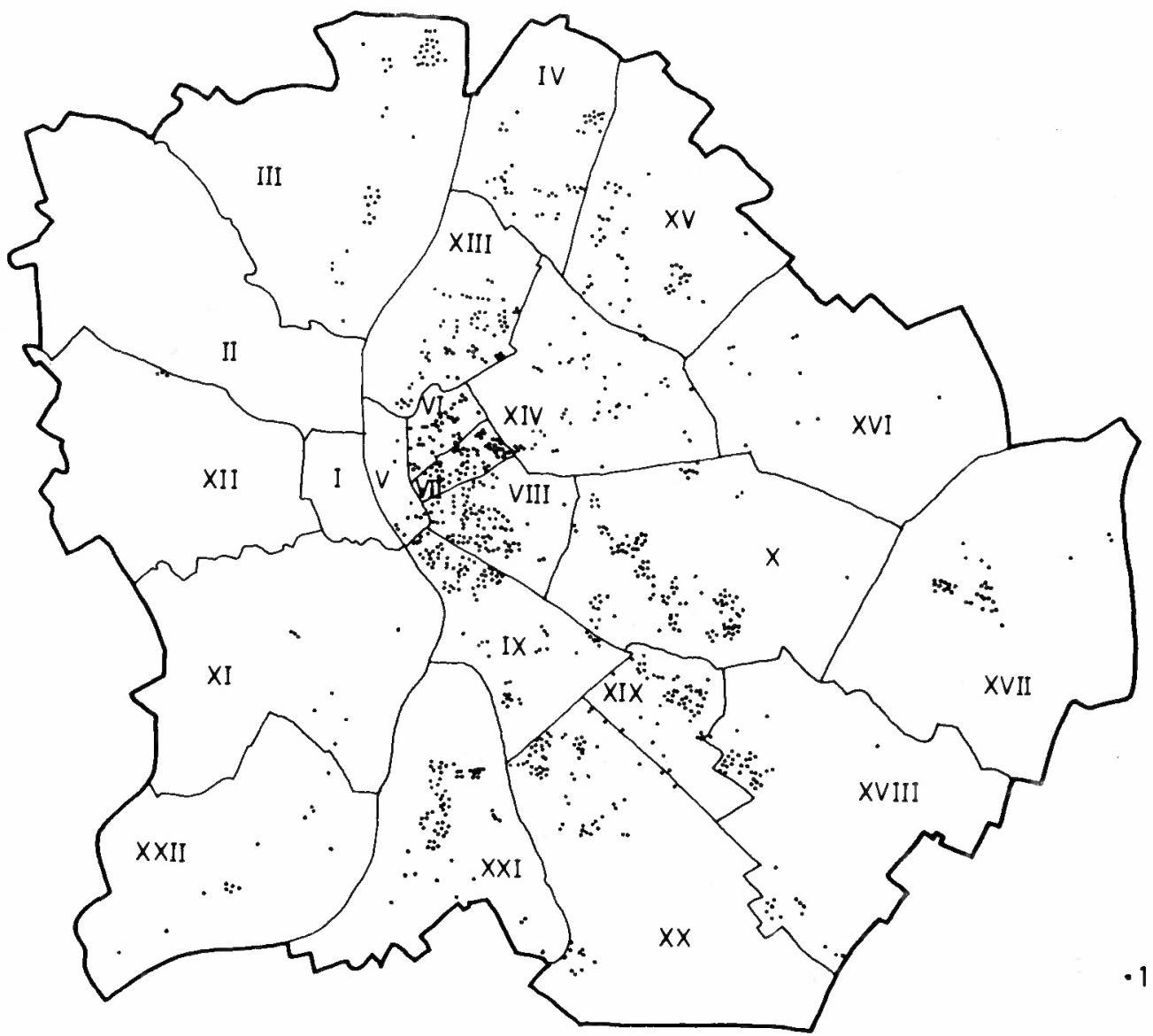

2. ÁBRA

A budapesti cigány népesség lakóhelyeinek sürüsödési pontjai Budapesten, 1980

(Residential distribution of gypsies in Budapest, 1980)

- = 3 lakóhely (Concentration of three residences) 


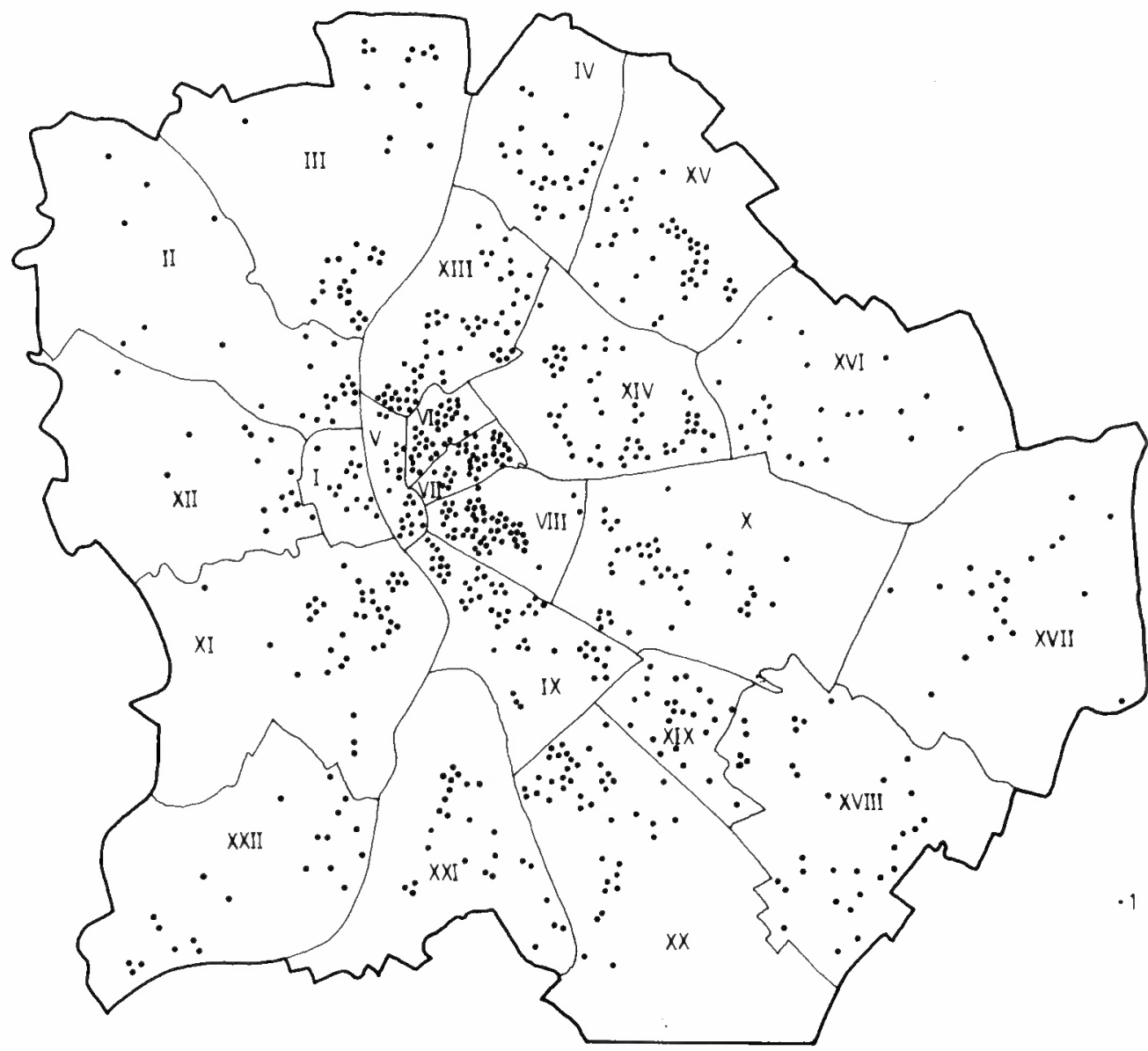

3. ÁBRA

Az 1979-ben börtönbüntetésüket töltók lakóhelyeinek sürüsödési pontjai Budapesten (Concentrations of imprisoned Budapest residents, 1979)

- = 3 lakóhely (Concentration of three residences) 
Ladányi János : Szabadságvesztés-büntetésüket töltők lakóhelyeinek térbeni elhelyezkedése Budapesten (Residential segregation of imprisoned offenders in Budapest)

Tér és Társadalom 5. évf. 1991/4. 17-35. p.

\section{A börtönbüntetésüket töltók különbözó csoportjai lakóhelyi szegregációjának intenzitása}

A továbbiakban a bebörtönzöttek különbözố csoportjai lakóhelyi elkülönülése mértékének eltéréseire, illetve ennek státussal való összefüggéseire vagyunk kíváncsiak. Ezért az elemzéshez eddig felhasznált 490 városrendezési körzet helyett ezek 11 csoportos társadalmi-foglalkozási összetétel szerint képzett clustereit fogjuk felhasználni. Ettôl az eljárástól azt reméljük, hogy a megközelítốleg azonos társadalmi státusú városrendezési körzetek azonos clusterbe kerülnek. Elổnye ennek az eljárásnak az is, hogy ily módon az általunk vizsgált viszonylag alacsony számú népesség lényegesen kevesebb területi egység között oszlik meg, ami az adatok megbízhatóságát emeli.

Különbözổ módszertani megfontolások után egyetlen, nem-hierarchikus clusterezési eljárás alkalmazása mellett döntöttünk. E módszerból következóen elổzetesen meg kellett határoznunk, hány clustert akarunk kialakítani. Miután a kialakítandó clusterek számát nehéz lenne egzakt és elméletileg is megalapozott eljárásokhoz kötni, kizárólag pragmatikus szempontok vezettek bennünket. Egymástól függetlenül hét és tizenöt clusterrel is elvégeztük számításainkat, majd - miután a kétféle eredmény az alaptendenciákat tekintve nem különbözött lényegesen egymástól - a részletességbeli különbségek miatt a tizenöt csoportos eljárás felhasználása mellett döntöttünk.

Clustereink társadalmi összetétele a következóképpen alakult (az alapadatokat az 1980. évi népszámlálás mágnesszalagokon tárolt személyenkénti adataiból állítottuk össze). (4. Táblázat)

Mint a 4. táblázatból látható, a 15 cluster közül háromnak $(2,11,14)$ igen alacsony a népessége. Ezért e clustereket a további elemzésekbốl ki fogjuk hagyni. A clusterek társadalmi összetételének részletes elemzésére e tanulmány keretei között nem térünk ki, csak annyit jegyzünk meg, hogy - mint ez a táblázatból is jól látható - az egyes clusterek státusának a fizikai dolgozók aktív keresốkön belüli aránya meglepổen jó közelítését adja. Ehhez hozzátehetjük azt a tapasztalatunkat, hogy a fenti jelenség fennáll nemcsak olyan viszonylag nagy területek, mint a clusterek, hanem lényegesen kisebb területi egységek, akár utcák, terek vagy házak lakóinak részletes foglalkozási összetételére vonatkozó adatok, illetve a fizikai/aktív mutató alapján mért státusa esetében is (Csanádi és Ladányi 1985). Mindez értelmezésünk szerint azt jelenti, hogy - legalábbis a különbözổ társadalmi csoportok Budapesten való elhelyezkedése esetében a társadalmon belüli legfontosabb választóvonal még mindíg a fizikai és szellemi munkát végzôk nagy csoportjai között húzódik. Mint a táblázatból látható, lényegében ugyanez mondható el a nyugdíjasok - technikai kényszerứségbốl - iskolai végzettség szerint kategorizált csoportjaira is. Ezek után a clustereket az elóbb említett arány szerint sorbarendezve közöljük a különbözó bủnözốcsoportok clusterenkénti arányait. 


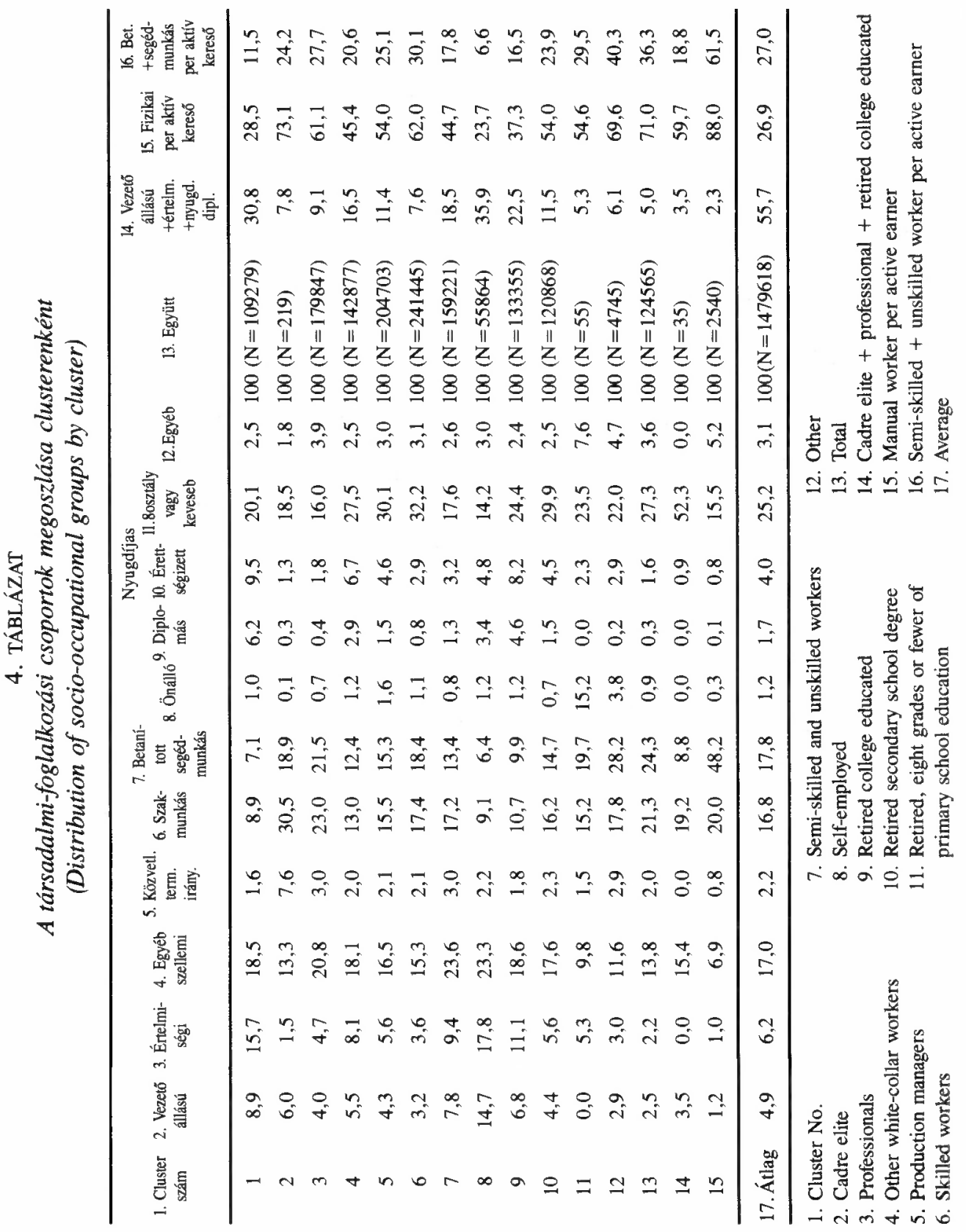


Ladányi János : Szabadságvesztés-büntetésüket töltők lakóhelyeinek térbeni elhelyezkedése Budapesten (Residential segregation of imprisoned offenders in Budapest)

Tér és Társadalom 5. évf. 1991/4. 17-35. p.

TÉT $1991 \cdot 4$

Szabadságvesztés-büntetésüket töltôk Budapesten

\section{TÁBLÁZAT}

Az 1979-ben börtönbüntetésüket töltók egyes csoportjainak aránya a 14 éven felüli népességen belül clusterenként, \%)

(Proportion of those who served their sentence in 1979 (in the over 14 years age group) and the linear correlation coefficients by cluster, \%)

\begin{tabular}{|c|c|c|c|c|c|c|c|c|c|c|}
\hline \multirow[b]{2}{*}{$\begin{array}{l}\text { 1. Cluster } \\
\text { szám }\end{array}$} & \multirow[b]{2}{*}{$\begin{array}{l}\text { 2. Népesség- } \\
\text { szám }\end{array}$} & \multicolumn{2}{|c|}{ 3. Elsó börtönbüntetés } & \multicolumn{2}{|c|}{ 5. Visszaesó } & \multirow{2}{*}{$\begin{array}{l}\text { 7. Els6 } \\
\text { börtön- } \\
\text { büntetés } \\
\text { összesen }\end{array}$} & \multirow{2}{*}{$\begin{array}{l}\text { 8. Vissza- } \\
\text { esơ } \\
\text { összesen }\end{array}$} & \multirow[b]{2}{*}{$\begin{array}{l}\text { 9. Keve- } \\
\text { sebb } 8 \\
\text { osztálynál }\end{array}$} & \multirow[b]{2}{*}{$\begin{array}{l}\text { 10. Több } 81 \\
\text { osztálynál }\end{array}$} & \multirow[b]{2}{*}{$\begin{array}{l}\text { l1. Össze- } \\
\text { sen }\end{array}$} \\
\hline & & $\begin{array}{l}8 \text { osztály- } \\
\text { nál keve- } \\
\text { sebb }\end{array}$ & $\begin{array}{c}4.8 \text { osz- } \\
\text { tálynál } \\
\text { több }\end{array}$ & $\begin{array}{l}8 \text { oszá́ly- } \\
\text { nál keve- } \\
\text { sebb }\end{array}$ & $\begin{array}{c}6.8 \text { osz- } \\
\text { tálynál } \\
\text { több }\end{array}$ & & & & & \\
\hline 8 & 61.525 & 0,07 & 0,24 & 0,11 & 0,10 & 0,31 & 0,21 & 0,18 & 0,34 & 0,52 \\
\hline 1 & 120.126 & 0,17 & 0,16 & 0,17 & 0,14 & 0,33 & 0,31 & 0,34 & 0,30 & 0,65 \\
\hline 9 & 145.280 & 0,19 & 0,34 & 0,42 & 0,29 & 0,35 & 0,71 & 0,61 & 0,63 & 1,25 \\
\hline 7 & 172.375 & 0,21 & 0,18 & 0,36 & 0,17 & 0,39 & 0,53 & 0,57 & 0,53 & 0,94 \\
\hline 4 & 154.810 & 0,33 & 0,30 & 0,59 & 0,28 & 0,63 & 0,88 & 0,92 & 0,58 & 1,52 \\
\hline 10 & 130.086 & 0,30 & 0,34 & 0,67 & 0,32 & 0,64 & 0,98 & 0,97 & 0,65 & 1,64 \\
\hline 5 & 221.528 & 0,38 & 0,27 & 0,73 & 0,40 & 0,65 & 1,13 & 1,11 & 0,67 & 1,80 \\
\hline 3 & 194.020 & 0,29 & 0,23 & 0,38 & 0,13 & 0,52 & 0,51 & 0,67 & 0,36 & 1,04 \\
\hline 6 & 259.989 & 0,39 & 0,36 & 0,75 & 0,32 & 0,75 & 1,06 & 1,14 & 0,67 & 1,85 \\
\hline 12 & 5.201 & 1,35 & 0,19 & 1,54 & 0,58 & 1,54 & 2,11 & 2,88 & 0,77 & 4,23 \\
\hline 13 & 134.716 & 0,48 & 0,23 & 0,82 & 0,33 & 0,71 & 1,15 & 1,31 & 0,56 & 1,91 \\
\hline 15 & 3.400 & 0,59 & 0,29 & 4,41 & 0,59 & 0,88 & 5,00 & 5,00 & 0,88 & 5,88 \\
\hline $\begin{array}{l}\text { 12. Össze- } \\
\text { sen }\end{array}$ & 1.603 .056 & 0,31 & 0,27 & 0,56 & 0,26 & 0,58 & 0,82 & 0,87 & 0,53 & 1,42 \\
\hline $\begin{array}{l}\text { 13. Korrelá } \\
\text { együtth }\end{array}$ & ciós & 0,38 & 0,02 & 0,51 & 0,24 & 0,30 & 0,46 & 0,53 & 0,14 & 0,43 \\
\hline
\end{tabular}

1. Cluster

2. No, of population

3. First imprisonment, less than eight grades of primary school

4. First imprisonment, more than eight grades of primary school

5. Recidivists, less than eight grades of primary school

6. Recidivists, more than eight grades of primary school

7. First imprisonment total

8. Recidivists total

9. Less than 8 grades of primary school

10. More than 8 grades of primary school

11. Total

12. Total

13. Correlational coefficient

Mint ez a fenti táblázatból látható, az összes börtönbüntetését töltốk clusterenkénti aránya és a fizikai dolgozók clusterenkénti aránya között viszonylag szoros, pozitív irányú összefüggés áll fenn. Továbbmenve az is megállapítható, hogy egyértelmû́ összefüggés áll fenn a börtönbüntetésüket töltốk különbözô státusú csoportjai clusterenkénti aránya, valamint a clusterek státusa között. Az alacsonyabb iskolázottságú, illetve a visszaesố bưnözók felülreprezentáltsága többnyire erốsebb az alacsonystátusú clusterekben, mint a magasabb iskolai végzettséggel rendelkezổ, illetve elsổ szabadságvesztésüket töltổ bûnözốké. 
Sokkal egzaktabb módon bizonyítja ugyanezt az összefüggést, ha megvizsgáljuk az egyes clusterekben a kvalifikálatlan fizikai dolgozók aránya, valamint a börtönbüntetésüket töltôk különbözố csoportjainak arányai közötti korrelációkat. Elsố pillantásra az tûnik szembe, hogy a 14 éven felüli népesség számával súlyozott lineáris korrelációs együtthatók meglehetốsen alacsonyak. Ez megfelel annak a korábban már említett ténynek, hogy a börtönbüntetését töltổ népesség lakóhelyeinek térbeni asszimetriája viszonylag alacsony. Összehasonlításként érdemes megemlíteni, hogy a börtönbüntetésüket töltốk 0,43-as korrelációs indexével szemben a cigány népesség clusterenkénti elhelyezkedésére számított korrelációs együttható csaknem $50 \%$-kal magasabb, vagyis 0,64 volt. A bebörtönzöttek egyes csoportjainak korrelációs együtthatói ezen a viszonylag alacsony szinten pontosan követik az egyes csoportok státusának alakulását. Az elsố szabadságvesztését töltố, viszonylag iskolázott bebörtönzöttek clusterenkénti elhelyezkedése szinte semmilyen összefüggést nem mutat a betanított és segédmunkások clusterenkénti arányával $(0,02)$. Ugyanakkor az iskolázatlan visszaesốk korrelációs együtthatója viszonylag magas $(0,51)$, ami újabb oldal ról világít rá e csoport viszonylag alacsony státusára, és lakóhelyeinek a város legalacsonyabbstátusú területein való tömörülésére. Az összes börtönbüntetésüket töltổ személyek clusterenkénti arányát mutatja be a 4. ábra.

E térképen jól láthatók azok az alacsony népességszámú clusterek, melyek többnyire a város kiesô részein, mezôgazdasági vagy ipari hasznosítású területeken helyezkednek el, és ahol az alacsony népességszámra vetítve igen magas a börtönbüntetésüket töltốk aránya. A 3. és 4. ábra összevetésébốl azonban az is nyilvánvalóvá válik, hogy ezekben az esetekben voltaképpen nem bũnözốk által magas arányban lakott, nagykiterjedésû̉ területekkel, hanem a nagyvárosi szegénység egyik, tipikusan mikroszegregátum jellegũ megjelenési formájával van dolgunk. Azzal az esettel, amikor a város legfélreesôbb részein elszórtan vagy kisebb-nagyobb tömörülésekben, általában igen rossz körülmények között, meglehetốsen alacsonystátusú családok élnek, akik körében a bủnözés is státusuknak megfelelôen magas arányban fordul elỏ. Bár az az ábránk, amely a bưnözốk arányát clusterenként, tehát meglehetôsen nagyméretû̉ területi egységenként mutatja be, nem igazán alkalmas a legalacsonyabb státusú népességet tömörító mikroszegregátumok térbeni elhelyezkedésének bemutatására, mégis igen figyelemreméltó, milyen pontosan különíti el a választott módszer a belsổ pesti kerületek magasabb státusú , ,belvárosi”" és alacsonystátusú ,,slumosodó” területeit. Említésre méltók azok a többnyire a pesti oldalon elhelyezkedổ szigetek is, amelyek általában magasabb státusú új lakótelepekkel vagy jobb családi házakkal beépített területeket jelölnek. Jól kivehetốk a térképen annak a nagykiterjedésũ, területileg összefüggố térségnek a körvonalai is, ahol igen alacsony volt a börtönbüntetésüket töltốk aránya. Ez a budai oldal többnyire hegyes-dombos területein, zömében magántulajdonú lakásokkal beépített térségekben található része minden eddig bemutatott térképünkön, minden eddig elemzett dimenzió szerint, a város legmagasabb státusú területe volt. Ezért az a tény, hogy a feltárt és börtönbüntetéssel szankcionált bủnesetek legalacsonyabb arányával jellemezhetố területi egységek szinte teljesen lefedik a város legmagasabb státusú területeit, újabb oldalról világít rá a börtönbüntetéssel szankcionált bửnözés gyakoriságának társadalmi meghatározottságára, illetve e társadalmilag determinált jelenség térbeni megjelenésének tényére. Ezt látszik megerősíteni az a körülmény is, hogy az adataink által lehetốvé tett módon kialakított egyes bünözổcsoportok térbeni elhelyezkedése lényegében az összes börtönbüntetését töltổ területi elhelyezkedésének fent ismertetett mintáját ismétli meg az adott csoport státusának meg 
Ladányi János : Szabadságvesztés-büntetésüket töltök lakóhelyeinek térbeni elhelyezkedése Budapesten (Residential segregation of imprisoned offenders in Budapest)

Tér és Társadalom 5. évf. 1991/4. 17-35. p.

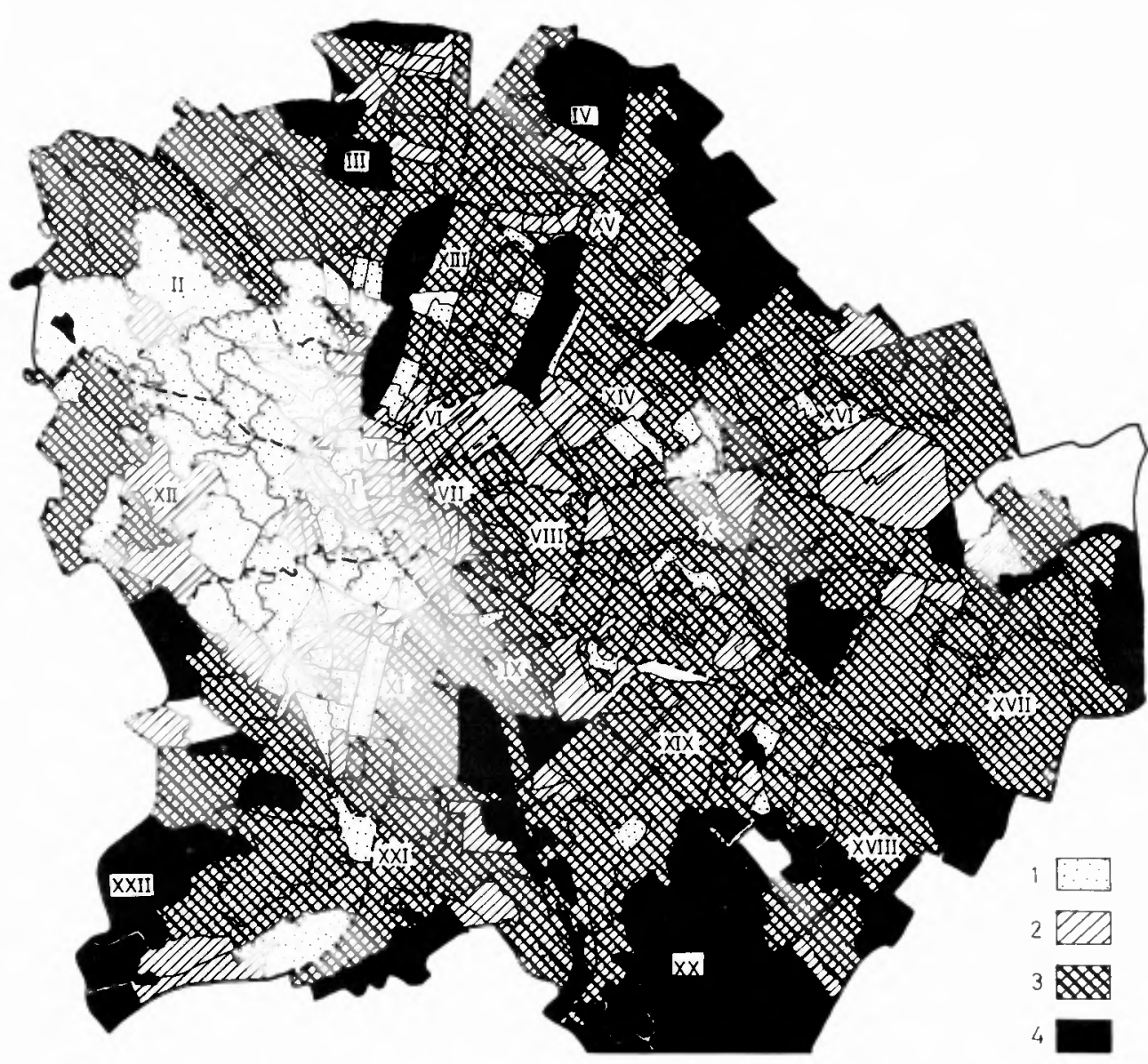

4. ÁBRA

Az 1979-ben börtönbüntetésüket töltók aránya clusterenként

(Residential distribution of imprisoned offenders in Budapest in 1970 by cluster)

$1=1 \%$ alatt (below $1 \%$ )

$2=1,0-1,5 \%$

$3=1,6-2,0 \%$

$4=2,0 \%$ fölött (above $2 \%$ ) 
Ladányi János : Szabadságvesztés-büntetésüket töltők lakóhelyeinek térbeni elhelyezkedése Budapesten (Residential segregation of imprisoned offenders in Budapest)

Tér és Társadalom 5. évf. 1991/4. 17-35. p.

felelổ szinten. A fenti okok miatt eltekintünk a börtönbüntetésüket töltốk egyes csoportjai térbeni elhelyezkedésének térképen történổ bemutatásától. Térbeni elhelyezkedésük asszimmetriájának fokát most már - jobban számszerứsíthetố módon - szegregációs indexekkel kíséreljük meg bemutatni.

\section{TÁBLÁZAT}

Az 1979-ben börtönbüntetésüket töltốk egyes csoportjainak szegregációs indexei a 14 éven felüli lakónépességhez viszonyítva, clusterenként

(Segregational indexes of imprisoned offenders in 1979 compared to the population over the age of 14 by cluster)

1. Elsố elsố szabadságvesztés, 8 osztálynál magasabb iskolai

csoport: végzettség

$10,5(\mathrm{~N}=435)$

$(\mathrm{N}=435)$

2. Második elsổ szabadságvesztés, legfeljebb 8 osztályos iskolai

csoport végzettség

$14,5(\mathrm{~N}=496)$

$(\mathrm{N}=496)$

3. Harmadik visszaesố, 8 osztálynál magasabb iskolai végzettség $16,1(\mathrm{~N}=424)$ csoport

$(\mathrm{N}=424)$

4. Negyedik visszaesô, legfeljebb 8 osztályos iskolai végzettség

$18,2(\mathrm{~N}=895)$

csoport

$(\mathrm{N}=895)$

1. Group 1. first imprisonment, more than 8 grades of primary school

2. Group 2. first imprisonment, maximum 8 grades of primary school

3. Group 3. recidivists, more than 8 grades of primary school

4. Group 4. recidivists, maximum 8 grades of primary school

Mivel a fenti csoportokat úgy alakítottuk ki, hogy közülük az elsổ három nagysága igen hasonló egymáshoz, csak a negyedik kategória esetében mondhatjuk el, hogy szegregációjuk a valóságban minden bizonnyal erôsebb, mint ez az itt közölt szegregációs indexek egymáshoz viszonyítása alapján látható. A fentieket röviden összefoglalva mindez tehát azt jelenti, hogy a szegregációs indexek alakulásának elemzése is megerôsíti azt a korábban már megfogalmazott következtetést, mely szerint a börtönbüntetésüket töltốk egyes csoportjai térbeni elkülönülésének erốssége e csoportok társadalmi összetételének függvényében alakul. Valószínũsíthetôn az is, hogy térbeni elkülönülésük mértékét tekintve egyfelôl az elsổ szabadságvesztésüket töltô, viszonylag iskolázottak, másfelốl pedig a visszaesố iskolázatlanok válnak el a másik két cso- 
Ladányi János : Szabadságvesztés-büntetésüket töltök lakóhelyeinek térbeni elhelyezkedése Budapesten (Residential segregation of imprisoned offenders in Budapest)

Tér és Társadalom 5. évf. 1991/4. 17-35. p.

TÉT 1991.4 Szabadságvesztés-büntetésüket töltók Budapesten

porttól, bár a legutóbbi megállapítás az ismertetett technikai körülmények miatt csak hipotetikus jelleggel állítható. Figyelemre méltó a középsố két csoport egymáshoz igen hasonló erổsségũ térbeni elkülönülésére utaló szegregációs indexe, és e csoportok elốbbitốl eltérổ sorrendje is. Ezért most az említett csoportok egymás közötti térbeli elkülönülését kifejező disszimilaritási indexek közül is megvizsgálunk néhányat.

\section{TÁBLÁZAT}

Az. 1979-ben börtönbüntetésüket töltók néhány csoportjának disszimilaritási indexei, clusterenként

(Dissimilarity indexes of some of the groups in prison in 1979 by cluster)

1. Csoportok

$(1)-(2)$
$(1)-(3)$
$(4)-(3)$
$(4)-(2)$

2. Disszimilaritási index

\begin{tabular}{lc}
\hline$(1)-(2)$ & 12,2 \\
$(1)-(3)$ & 11,4 \\
$(4)-(3)$ & 8,6 \\
$(4)-(2)$ & 6,8 \\
\hline
\end{tabular}

1. Groups

2. Dissimilarity indexes

Mint láttuk, az elsỗ szabadságvesztésüket töltổ viszonylag iskolázatlanok, és a visszaesổ viszonylag iskolázottak szegregációs indexei egymáshoz igen hasonlóan alakultak. Az említett két csoportnak a hierarchia két pólusán elhelyezkedő csoportoktól mért elkülönülésének elemzése is a két középső csoport sorrendjének határozatlanságára utal. Sớt, a disszimilaritási indexek elemzése alapján úgy tũnik, hogy az egyes csoportok térben inkább elkülönülnek egymástól a társadalmi státussal közvetlenebb kapcsolatban álló iskolai végzettség, mint a szabadságvesztés elsơ, vagy annál gyakoribb volta alapján.

Eddig a börtönbüntetésüket töltốk különbözố csoportjait csak iskolai végzettségük és szabadságvesztésük száma szerint vizsgáltuk. Nyilvånvaló, hogy ezek a csoportok igen heterogének, és többé-kevésbé releváns csoportosítás kialakításához legalább a bưnelkövetés módjának ismeretére lenne szükség. Sajnálatos módon ilyen adatok nem állnak rendelkezésre részletes lakóhely szerinti bontásban, azonban ismerjük az összeírt személyek által az akkori szabadságvesztés során az összeírás idổpontjáig börtönben töltött évek számát, ami igen erôsen korrelál a bünelkövetés módjával.

Az adatok tanusága szerint a szegregációs indexek a börtönben töltött évek számával párhuzamosan valamelyest emelkednek. Ez az emelkedés azonban részben az esetszámok csökkenésével magyarázható, részben pedig annak a ténynek tudható be, hogy a hosszabb börtönbüntetésre itéltek körében magasabb az alacsony iskolai végzettséggel rendelkezô, alacsonystátusúak aránya. Ez utóbbi részben annak az ismert összefüggésnek tulajdonítható, hogy a hátrányos helyzetû́ társadalmi csoportokból kikerülốk tájékozatlanságuk, megfelelỗ védelmük hiánya stb. miatt ugyanolyan vétségért gyakran hosszabb börtönbüntetést szenvednek, mint elổnyösebb helyzetû́ társaik. 
Ladányi János : Szabadságvesztés-büntetésüket töltők lakóhelyeinek térbeni elhelyezkedése Budapesten (Residential segregation of imprisoned offenders in Budapest)

Tér és Társadalom 5. évf. 1991/4. 17-35. p.

$32 \quad$ Ladányi János

TÉT 1991 -4

\section{TÁBLÁZAT}

Az 1979-ben börtönbüntetésüket töltók egyes csoportjainak szegregációs indexei clusterenként és a börtönben töltött idố szerint

(Segregational indexes of imprisoned offenders in 1979 by number of years in prison and cluster)

\begin{tabular}{|c|c|c|c|c|c|c|}
\hline & & & & & \multirow{2}{*}{\multicolumn{2}{|c|}{ 3. Összesen }} \\
\hline & \multicolumn{4}{|c|}{ hosszabb ideje börtönben } & & \\
\hline & $\begin{array}{l}\text { 4. szegr. } \\
\text { index }\end{array}$ & $\mathbf{N}$ & $\begin{array}{l}\text { szegr. } \\
\text { index }\end{array}$ & $\mathrm{N}$ & $\begin{array}{l}\text { szegr. } \\
\text { index }\end{array}$ & $\mathrm{N}$ \\
\hline $\begin{array}{l}\text { 5. } 8 \text { osztálynál ala- } \\
\text { csonyabb iskolai } \\
\text { végzettség }\end{array}$ & 19,4 & 485 & 21,1 & 293 & 16,8 & 1391 \\
\hline $\begin{array}{l}\text { 6. } 8 \text { osztálynál ma- } \\
\text { gasabb iskolai } \\
\text { végzettség }\end{array}$ & 14,5 & 232 & 18,3 & 137 & 12,4 & 859 \\
\hline $\begin{array}{l}\text { 7. Elsố szabadság- } \\
\text { vesztés }\end{array}$ & 16,8 & 259 & 18,1 & 163 & 10,6 & 931 \\
\hline 8. Visszaesố & 20,0 & 458 & 20,5 & 267 & 17,3 & 1319 \\
\hline 9. Átlag & 17,4 & & 18,4 & & 14,6 & \\
\hline
\end{tabular}

1. More than 3 years in prison

2. More than 4 years in prison

3. Total

4. Segregational index

5. Less than 8 grades in primary school

6. More than 8 grades in primary school

7. First imprisonment

8. Recidivist

9. Average

Mindezek alapján megállapíthatjuk, hogy ezek az adatok semmiképpen sem igazolják a város meghatározott pontján, vagy pontjain éló, meghatározott bưnelkövetési módokra specializálódott bưnözôi szubkultúra tömeges jelenlétéról hangoztatott véleményeket. Ugyanezt látszik alátámasztani a börtönbüntetésüket töltôk lakóhelyeit bemutató ábrák részletes elemzése is. A különbözô áltudományos és álobjektív rendôri és szociográfikus beszámolókban , ,bûnözés által fertốzöttnek" bemutatott városrészekben általában nem magasabb a börtönbüntetésüket töltôk aránya, mint amit ezen városrészek alacsony státusa indokol. 
Ladányi János : Szabadságvesztés-büntetésüket töltök lakóhelyeinek térbeni elhelyezkedése Budapesten (Residential segregation of imprisoned offenders in Budapest)

Tér és Társadalom 5. évf. 1991/4. 17-35. p.

TÉT 1991 - 4

Szabadságvesztés-büntetésüket töltók Budapesten

\section{Néhány következtetés}

Az 1979-ben börtönbüntetését töltổ budapesti népesség lakóhelyi szegregációjának elemzése e népességcsoport lakóhelyeinek közepesen erôs térbeni elkülönülését bizonyítja. A vizsgált népességcsoport egésze és különbözổ szempontok alapján képzett csoportjai lakóhelyi szegregációjának erôssége és mintái nem térnek el lényegesen attól, amit e csoportok státusa önmagában is indokol.

Különbözô adatokból tudjuk, hogy Magyarországon a bű̉nelkövetések gyakorisága az utóbbi évtizedben erôsen emelkedett. A hátrányos társadalmi helyzet és a bủnözés összefüggésének alaptendenciái azonban sokkal erốsebben determinált társadalmi ősszefüggések annál, hogy ilyen viszonylag rövid idôszak alatt gyökeresen átalakulhassanak (Tauber 1986; Vigh et. al. 1988). A bû̉nelkövetések gyakoriságának emelkedése egyrészt szükségszerũen következik az országban azóta végbemenô demokratikus átalakulásból, a külföld felé való összehasonlíthatatlanul nagyobb nyitottságból, a rendổri módszerek jogi korlátozásának fokozódásából stb. Röviden úgy fogalmazhatnánk, hogy mintegy a demokratikus átalakulás igen kevés negatív hatásai közé sorolható. A bứnözés emelkedése másrészt - szerintünk döntôen - a válság által kiváltott normavesztésból, a reményvesztettség és létbizonytalanság fokozódásából, egyes társadalmi csoportok életszínvonalának csökkenésébốl következik.

Teljesen megértjük a társadalom aggodalmát amiatt, hogy újabb nemkívánatos területen sikerült felzårkóznunk Nyugat-Európához, miközben gazdasági lemaradásunk mértéke tovább fokozódott. Elítéljük viszont a különbözố rendốri és rendốrséghez közelálló körök e jelenséggel kapcsolatos manipulációit. E körök ma apokaliptikus képet festenek a nyugat-európai országokénál általában még mindig alacsonyabb magyar bưnözésrôl, a nyugati városokénál még mindig kedvezóbb budapesti közbiztonságról. Ezt elsốsorban azért teszik, mert alapvetố érdekeik a korábbi rendốrállamhoz kötik ôket, ezért a demokratikus társadalomba való átmenet közepette a politikai zavarkeltésben érdekeltek.

A magyarországi bünözésrôl festett apokaliptikus kép eddig mindig a rendổrségre fordított kiadások radikális emeléséhez szolgált ürügyül. E pótlólagos ráfordítások igen nagy részét eddig mindig a politikai ügyekkel foglalkozó rendổi részlegek kapták meg. A rendốrség legfontosabb feladata az volt, hogy az állam politikai berendezkedésének stabilitásán ốrködjön, miközben az állam polgárainak védelmét szolgáló bứnüldözés technikai feltételei nem tartottak lépést a bửnözés emelkedése által megkívánt helyzettel. A búnözéssel és bũnüldözéssel kapcsolatos adatok tekintélyes részét a Belügyminisztérium titkosan kezelte, ami meggátolta, hogy a társadalomnak e kérdésekrốl objektív információi legyenek. Erre pedig igen nagy szükség lenne, mert a manipulatív célokkal kialakított és terjesztett kép állandó ủrügyül szolgált és szolgál ma is különbözó , ,rendpárti", valójában antidemokratikus, gyakran kisebbségellenes intézkedések hangos követeléséhez. Hangulatkeltố nyilatkozatok és kiszámíthatatlan, hisztérikus fellépés helyett, pontos helyzetértékelésre és határozottan, de törvényesen fellépó rendôrségre volna tehát szükség.

Tanulmányunk talán néhány adalékkal szolgálhat a bứnözésnek és a hátrányos társadalmi helyzetnek a nagyvárosi térszervezôdésben is megmutatkozó összefüggéseirôl. Úgy gondoljuk, hogy a most születốben levổ magyarországi demokráciának a korábbinál erôsebb és hatéko- 
nyabb bünüldözố apparátusra van szüksége. A bû̉nmegelôzésért folytatott küzdelem azonban nem sértheti a bũnt el nem követố polgárok magánéletét, és a bũnözốk börtönbốl való szabadulása utáni ellenôrzésének is a társadalomba való visszailleszkedés és nem a törvénytelen retorziók ügyét kell szolgálnia. Ezért a bũnmegelôzzési feladatokat ki kell venni a bûnüldözéssel foglalkozó apparátus kezébớl. Ezzel párhuzamosan a rendốrség bünüldözési munkáját igen szigorú alkotmányos garanciákkal alátámasztott parlamenti kontroll alá kell vonni.

A lehetôségét is meg kell akadályozni annak, hogy bizonyos társadalmi erốk szociális problémákat rendôri módszerekkel akarjanak megoldani, hogy szociális demagógiával újra rendôrállamot akarjanak ránkkényszeríteni!

(Budapest, 1990. nyarán)

\section{Irodalom}

Csanádi G. - Ladányi J. (1985) Budapest - a városszerkezet történetének és a különbözố társadalmi csoportok városszerkezeti elhelyezkedésének vizsgálata (Budapest - a study of the history of urban structure and the residentiel segregation of the different social groups), Budapesti Közgazdasági Egyetem, Budapest.

Duncan, O.D. and Duncan, B. (1955) Residential distribution and occupational stratification. American Journal of Sociology, március.

Ladányi J. (1988) A lakóhelyi szegregáció alakulása Budapesten 1930 és 1980 között, Valóság, 3.

Ladányi J. (1989) A lakásrendszer változásai és a cigány népesség térbeni elhelyezkedésének átalakulása Budapesten, Valóság, 8.

Tauber, I. (1986) A hátrányos társadalmi helyzet és a bünözés összefüggései, különös tekintettel egyes kisebbségi csoportokra, Tankönywiadó, Budapest.

Vigh, J. et. al. (1988) A hátrányos társadalmi helyzet és a bünözés kapcsolata, BM Könyvkiadó, Budapest.

\section{RESIDENTIAL SEGREGATION OF THE IMPRISONED OFFENDERS IN BUDAPEST}

\section{JÁNOS LADÁNYI}

In this study, the author summarizes the results of research into the spatial segregation of imprisoned offenders in the capital city of Hungary. Using data on the place of residence of imprisoned offenders in 1979 in Budapest, it also assesses police claims that there are areas of Budapest where there are high concentrations of offenders. One focus is a comparison of these concentrations of offenders with the most disadvantaged group in Hungarian society, the gypsies.

The sample of offenders studied in this project (2,284 individuals) consisted of those over 18 years of age serving the sentences in Hungary on the 31 October 1979 and gave Budapest as their permanent or temporary address (but not those living in workers' hostels or reformatory schools).

The initial analysis of the spatial distribution of the imprisoned offenders involved their grouping, and then their plotting on a detailed map of Budapest showing each house and plot. The different groups of offenders were plotted with different colour. In the first step, the differ- 
ent - colour dots were added by census tracts (there were 490 such tracts in Budapest in 1980), and the resulting data, together with some other census data, were processed by computer. The greatest advantage of the above plotting method was that this way, not only the distribution of the investigated phenomenon by census tracts could be revealed, but also the overlapping, or small concentrations became visible. In the first step, the distribution of the population in question was investigated in those dimensions which facilitated the comparison with the capital city's average population.

According to the data, the imprisoned offenders are much less educated than the average population of Budapest. This difference is even more striking if we take into consideration that the imprisoned offenders are usually younger, and the younger generations usually have higher educational level. In the case of imprisoned offenders, $60 \%$ finished 8 grades of the elementary school as a maximum, and if they participated in secondary education at all, that was vocational training, and only every 50 th of them has some sort of higher education. As opposed to this, only $50 \%$ of the inhabitants of Budapest, who are usually older, have maximum 8 grades of elementary education, if they participated in secondary education, that was more likely secondary grammar school than vocational training, and every 8th of them have some sore of diploma.

When examining the residential segregation of imprisoned offenders, the author first summarizes the segregational patterns of different social and ethnic groups. The author indicates that the spatial segregation of these different groups is characterized by the contrast between the large concentration of high-status groups in parts of Buda and the dispersed but clearly definable small areas of low-status groups on the Pest-side of the capital. The area where gypsies live in the slums of inner Pest, however, forms a large, coherent area. The spatial distribution of imprisoned offenders is more even, except that they tend to be over-represented in the inner, slum areas of Pest and under-represented in the high-status parts of Buda.

When examining the segregational indexes of the different groups of imprisoned offenders created by their educational level, the number of imprisonments and the time spent in prison it could be concluded, that the data on imprisoned offenders in Budapest do not support the view that there is a mass criminal subculture living in a certain part or parts of the city. Furthermore, in those parts of the city which are portrayed as ,,criminal areas" in police reports, such as the inner city slum areas of Pest, the proportion of imprisoned people is usually no higher than the proportion one would expect given the low status of the people living in these areas.

Translated by J. Mészáros 